\title{
OVERVIEW OF ODOUR MEASUREMENT METHODS: THE ODOUR OBSERVATORY AS AN INFORMATIVE TOOL FOR CITIZEN SCIENCE BASED APPROACHES TO ODOUR MANAGEMENT
}

\author{
Laura Capelli ${ }^{1, \star}$, Rosa Arias ${ }^{2}$, Jose Uribe-Echevarria ${ }^{3}$ and Selena Sironi ${ }^{1}$ \\ ${ }^{1}$ Department of Chemistry, Materials and Chemical Engineering "Giulio Natta", Politecnico di Milano, P.za Leonardo da Vinci 32, 20133 \\ Milan, Italy \\ ${ }^{2}$ Ibercivis Foundation, Campus Río Ebro, R\&D Building, C/ Mariano Esquillor, s/n, 50018 Zaragoza, Spain \\ ${ }^{3}$ International Solid Waste Association (ISWA), Stationsplein 45, 3013 AK, Rotterdam, The Netherlands
}

Article Info:

Received:

27 November 2019

Revised:

26 Februaryl 2020

Accepted:

30 April 2020

Available online

7 September 2020

Keywords:

Odour impact assessment

Olfactometry

Odour pollution

Odour emissions

Ambient air

Odour monitoring

\begin{abstract}
Odour pollution is a well-known problem related to a number of different industrial activities. It is also one of the main causes of citizens' complaints to local authorities. Specific programs are needed to manage persistent odour pollution problems within communities in order to avoid possible socio-environmental conflicts. The H2020 project D-NOSES (Distributed Network for Odour Sensing, Empowerment and Sustainability) aims to help citizens co-create local solutions in collaboration with industries, regional \& local authorities, and odour experts. The project will develop an innovative bottom-up approach to odour pollution governance by combining citizen science and stakeholder management methods using a quadruple helix model. The first aim of this article is to introduce the D-NOSES project and its methodology. Aside from that, the article presents an overview of the existing odour impact assessment methods currently available to quantify odour pollution. Finally, the different odour measurement methods are compared in terms of their applicability and limitations. This overview will be made available online as a first step towards the development of the International Odour Observatory, a platform to be created within the D-NOSES project to help promote odour pollution management and resolve regulation issues. The platform will become a global resource on odour issues and also include information about odour abatement systems, chemical substances in odour emissions, and odour regulations around the world.
\end{abstract}

\section{INTRODUCTION}

Odour pollution is a recognised problem related to a number of different industrial activities, and one of the main causes of citizens' complaints to local authorities (Henshaw et al., 2006). This is particularly true when waste treatment facilities are involved (Lucernoni et al., 2017; Marchand et al., 2013; Sironi et al., 2006). Although odour emissions are generally considered harmless, in some cases they may cause adverse health effects for citizens that go beyond mere inconvenience (Aatamila et al., 2011). In order to avoid socio-environmental conflicts within the impacted communities, specific programs are needed to manage odour pollution problems.

Combining Citizen Science and participatory strategies, the H2020 project D-NOSES (Distributed Network for Odour Sensing, Empowerment and Sustainability) will help citizens to co-create local solutions together with industries, regional \& local authorities, as well as odour experts.
Ten pilot projects will be conducted in ten European and non-European locations to validate the methodology. Each pilot will involve encouraging local citizens to collect data and use a variety of different techniques for validation. The pilot groups will then employ a stakeholder engagement methodology to improve the management of odour pollution issues within their own local context. D-NOSES will promote the idea that using citizen science to monitor odour pollution is a logical choice since citizens are naturally equipped with the best sensor available to measure odours, i.e. their own noses. A mobile app (OdourCollect, https://odourcollect.eu/) was specifically created for the project, providing a platform that allows citizens to easily gather odour observations and co-create odour maps of affected communities.

In addition, the project will create the International Odour Observatory in order to provide a comprehensive global resource for odour management issues. The ob- 
servatory will gather odour data, raise awareness, and make relevant environmental information available to all interested stakeholders. There will be a section devoted to compiling the scientific and regulatory frameworks currently used to manage odour pollution around the world. This section will also provide other useful and relevant information such as the chemicals that are commonly associated with odour emissions from different activities, the systems that can be used to reduce these odour emissions, and finally an overview of any existing odour regulations in different regions.

The observatory aims to educate stakeholders at all different levels, and in particular ordinary citizens, concerned with odour pollution. One of the most common questions regarding odour pollution from citizens is whether odours can be effectively measured. For this reason, one of the first objectives for the Odour Observatory is to explain how odours can be measured and provide an overview of the methods that can be used for this purpose. Furthermore, the observatory will make clear that it is not just about measuring odours, but rather it is also important to be able to assess odour impacts in a simplified and accessible manner.

This paper has the aim to introduce the D-NOSES project and its methodology, and to present an overview of the existing odour measurement methods that can be applied to quantify odour pollution and impacts. By gathering this information the Odour Observatory made available through the D-NOSES project can be used in the future to compare different methods and help foster a common approach based on best-practices. Some recent review papers are also referenced, provide relevant examples of how such different techniques have been applied in different situations (Conti et al., 2020; Guffanti et al. 2018).

\section{THE D-NOSES PROJECT: OVERALL AIMS AND STRATEGY}

The overall aim of the D-NOSES project is to develop and validate a methodology for odour pollution management based on a bottom-up approach. This approach focuses on using participatory strategies for citizen involvement, engagement with a broad set of quadruple helix stakeholders, and the co-creation of practical and balanced solutions. The project intends to:

- Raise awareness about odour pollution, and address related environmental and sanitation problems, at global, national and local levels.

- Pave the way for increased sustainability and quality of life through a multi-level engagement strategy to resolve odour issues and related conflict situations;

- Provide easy access to information for all stakeholders through the International Odour Observatory;

- Collect evidence through 10 local case studies in European and non-European countries to validate the methodologies;

- Provide common scientific guidelines for policymaking;

- Produce a Green Paper and a Strategic Roadmap for Governance in odour pollution to advocate and inform the development of common, bottom-up, efficient and coherent regulations.

According to the above listed points, one of the Work Packages (WPs) of the project is devoted to the description of the current scientific and regulatory frameworks for odour pollution across different regions.

This knowledge base will be one of the pillars of the International Odour Observatory, the purpose of which will be to provide a single point of reference for all stakeholders involved with odour pollution issues. Indeed, in order to reach the goal of creating common scientific guidelines for policy making, it is extremely important to define the problem by identifying relevant odour sources, up-to-date techniques for odour impact assessment and abatement, as well as current policies and regulations in European and extra-European countries.

\section{THE INTERNATIONAL ODOUR OBSERVA- TORY}

\subsection{The Odour Observatory as an informative tool for citizens}

Despite being the second most common reason for environmental complaints in Europe (Marchand et al., 2013), information and advice about odour pollution can be hard to find. The level of knowledge about fundamental aspects related to odour pollution tends to be scarce, especially among ordinary citizens. In fact, it is not rare to hear such basic questions as: "What is an odour?" or "Is there a way to measure odours?". This lack of basic knowledge could severely limit the possible success of any proposed bottom-up methodology for the management of odour pollution problems. In recognition of this limitation, one of the main objectives of the D-NOSES project is the creation of the "International Odour Observatory". The observatory will help to communicate the required knowledge for all stakeholders to participate effectively in a citizen science based methodology for odour governance. Further, the observatory will also help gather data about specific odour pollution problems and make any relevant and actionable environmental information available to all interested stakeholders.

More specifically, the Odour Observatory will have a "Get informed" section (Figure 1) containing information on which regulations apply in different parts of the world, how odours can be measured and all other relevant information related to odour pollution. The information will be made available at different levels of complexity, targeting the differing interests and requirements of each specific stakeholder. This section will be considered as a first step in educating stakeholders about odour pollution and will provide a natural entry point to get them more actively involved in odour issues.

\subsection{Structure of the section describing how odours can be measured}

One of the main questions that the Odour Observatory will answer is on how odours can be measured. A preliminary document was created providing a classification scheme for the identified methods for odour measurement. 


\section{What does the World Smell Like?}

We are excited to introduce to you the International Odour Observatory, one of the main and lasting results of the D-NOSES project that will carry on the work of empowering citizens to tackle odour pollution in their own communities.
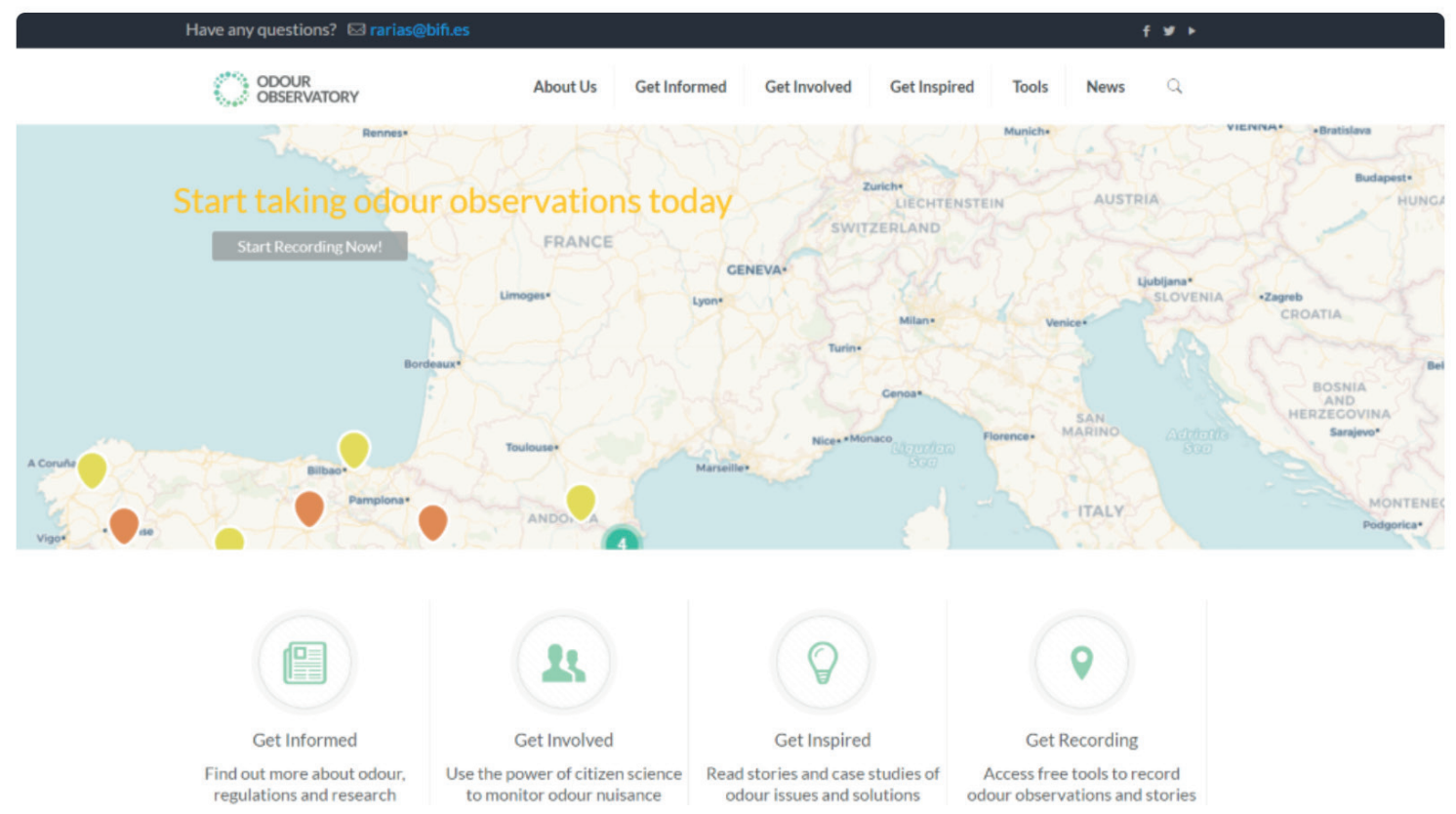

FIGURE 1: Example of homepage of the Odour Observatory (under construction).

Within the Odour Observatory, , each method is described briefly and simply by answering the following questions:

- What is it? (Method description)

- What can it be used for? (Applicability)

- What can it not be used for? (Limitations)

Each entry is further complemented with some examples of relevant applications as well as a list of links to selected reference articles for further detailed information. This way the observatory can serve the needs of both a technical as well as a lay audience.

This paper is limited to the schematization of the methods and to their brief description according to the above-reported list of questions. For more detailed information about relevant applications described in the scientific literature, please refer to Capelli et al., 2019.

\section{OVERVIEW OF ODOUR MEASUREMENT METHODS}

\subsection{General schematization of odour impact assess- ment methods}

As a first step, the existing odour impact assessment methods were identified, and an attempt was made to schematize them according to the type of method (mathematical methods, instrumental measurements and sensorial measurements) and depending on where they can be applied (emissions vs. ambient air). The resulting scheme is shown in Figure 2 (Capelli et al., 2019).

In order to provide an overview of the existing odour impact assessment methods, the following paragraphs present a very short description of each method, then the last paragraph provides a comparison of the different methods in terms of applicability and limitations. Currently this overview only focuses on practical methods for odour measurement, leaving out mathematical methods.

\subsection{Dynamic olfactometry}

Dynamic olfactometry is a standardized sensorial technique for measuring odour concentrations using the human sense of smell (CEN, 2003). It is related to the sensation caused by a sample directly on a panel of opportunely selected people.

The outcome of this measurement is the odour concentration of the sample, expressed in European odour units per cubic meter $\left(\mathrm{ou}_{\mathrm{E}} / \mathrm{m}^{3}\right)$. This represents the number of times the sample has been diluted with neutral air to reach its odour detection threshold concentration. Thus, if the sample needs to be diluted 100 times with clean air so that the panel cannot perceive the odour anymore, this means that the sample has a concentration of $100 \mathrm{ou}_{\mathrm{E}} / \mathrm{m}^{3}$.

Samples of odorous air are collected at the source of the odour in bags. The analysis is carried out by presenting the sample to the panel at increasing concentrations by 


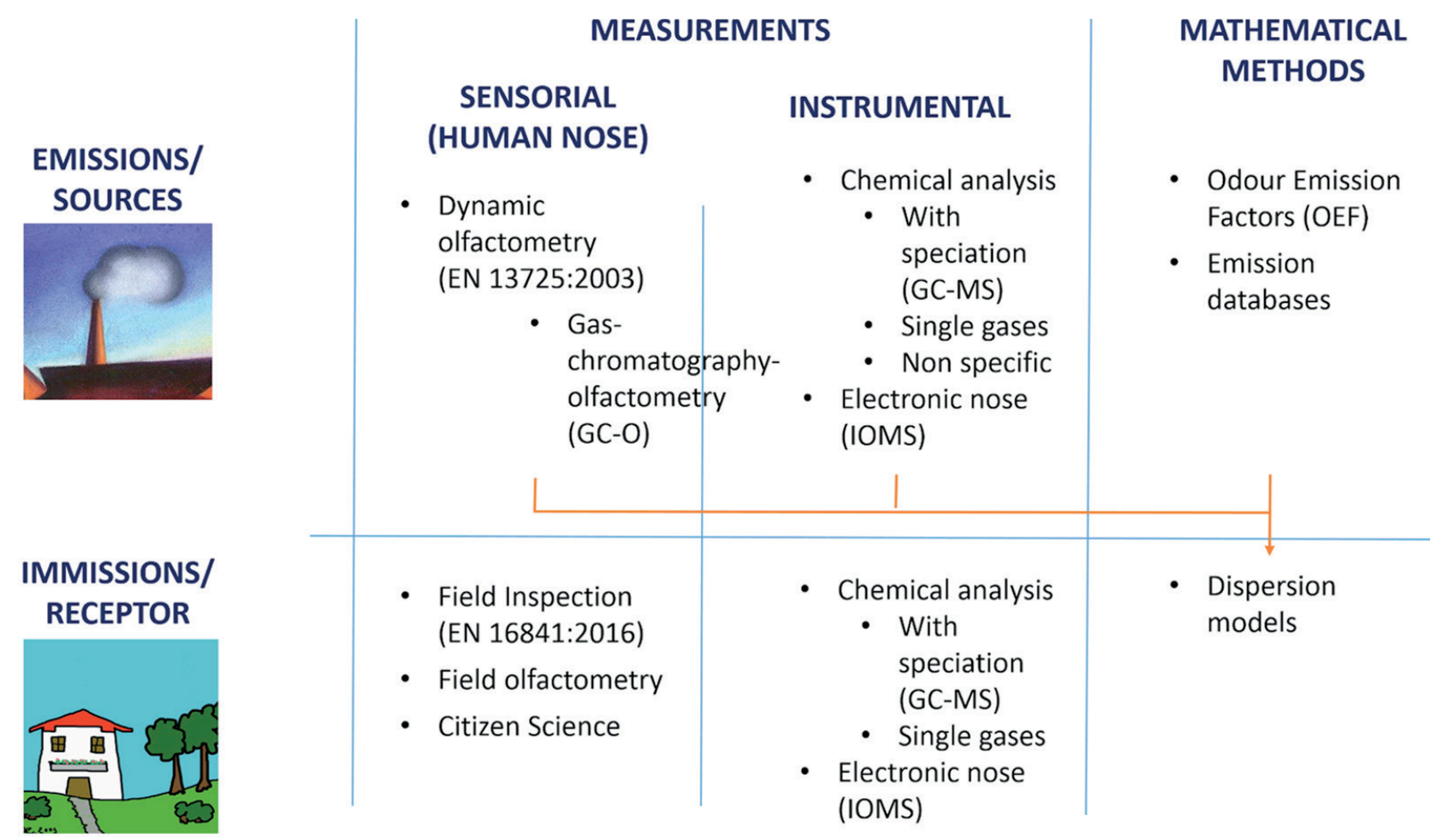

FIGURE 2: Schematization of odour impact assessment methods.

means of a dilution device called an olfactometer, until the panel members can detect an odour that is different from the reference air.

Results of olfactometric analyses can be used as inputs for dispersion models in order to evaluate impacts on receptors (Sironi et al., 2010; Sowka et al., 2016).

\subsection{Chemical analysis - with speciation}

Chemical analysis (with speciation) of odours is an instrumental analysis for the complete identification and quantification of odorous chemical compounds in an odour sample (e.g., Ávila et al., 2014; Davoli et al., 2003; Rodríguez-Nava et al., 2012; Zhao et al., 2015). It is an "instrumental analysis": the main technique is Gas Chromatography coupled with Mass Spectrometry (GC-MS). GC MS is a technique that combines the separation capability of gas chromatography (GC) with mass spectrometry (MS) for the identification of the separated compounds.

GC can separate different molecules depending on their chemical-physical properties. After separation, MS breaks each molecule into ionized fragments, obtaining a mass spectrum. A mass spectrum can be considered to be the fingerprint of a molecule. It is characteristic to each molecule and can be used to uniquely identify a substance.

\subsection{Gas-chromatography-Olfactometry (GC-0)}

This is a method that combines the information provided by chemical characterization and odour perception. GC-O utilises a GC-MS system equipped with an olfactory detection port. At the outlet of the GC is a sniffer mask through which a trained panelist can smell the gas and provide information about the presence of odour in it. GC-MS-O enables simultaneous chemical and sensorial analysis, which can be particularly useful in identifying compounds that are responsible for the overall odour perceived by the human nose (Wright et al., 2005; Zhang et al., 2015).

\subsection{Chemical analysis - non-specific}

In cases where the odour problem is specifically related to hydrocarbon molecules, such as oil refineries and landfills (Singh et al., 2013; Kormi et al., 2018), a non-specific gas analysis can be applied as a preliminary screening tool to assess the total amount of hydrocarbon compounds. This can be done using easily transportable and inexpensive tools like FID (flame ionization detector) or PID (photo ionization detector) (Samir and Hossain, 2014).

These tools are based on the pyrolysis of the organic compounds using some sort of energy source (hydrogen flame for FID, UV lamp for PID). The pyrolisis produces ions which are detectable by an electric sensor.

\subsection{Chemical analysis - single gases}

In those rare cases in which the odour pollution problem is due mainly to a single compound, such as $\mathrm{NH} 3$ or $\mathrm{H}_{2} \mathrm{~S}$, a reliable quantification of odours (in emissions or in ambient air) can be obtained by assessing the concentration of these single gases (Wang et al., 2014). However, it should be highlighted that the situations in which complex environmental odours can be represented by just one tracer compound are rare.

There are specific technical norms that define the sampling and analysis methods for the measurement of sin- 
gle gases in emissions. When the concentrations are quite high (1-10 ppm) it is possible to use electrochemical sensors, which are easy to use and cheap.

When applying the analysis of single gases to ambient air, the compound to be measured should not be ubiquitous; its source must be clearly identifiable. When concentrations are low, more complex and expensive tools are needed, like a chemiluminescence analyzer for $\mathrm{NH}_{3}$ or gold foil instruments for $\mathrm{H}_{2} \mathrm{~S}$.

\subsection{Instrumental odour monitoring (E-noses)}

An electronic nose is a piece of equipment designed to mimic mammalian olfaction for the detection and characterization of simple or complex odours.

These devices allow the identification of mixtures of organic samples as a whole, providing their olfactory fingerprint, without recognizing the individual odor-generating compounds. Much in the same way that the human nose doesn't need to identify each single odorant molecule in order to distinguish the odour of an apple from the smell of rotten eggs.

To do this, the instrument must be trained: it must be provided with a database of olfactory fingerprints of the odours it may be exposed to during the analysis. That database is put together by analyzing air samples with known olfactory qualities at different odour concentrations and thus defining the olfactory classes (odour types) to be recognized.

Today, electronic noses are increasingly applied in the continuous monitoring of odours from different types of facilities (Deshmukh et al., 2015; Cipriano et al., 2019).

\subsection{Field inspection}

The main idea behind field inspections is to estimate the degree of annoyance in a determined problematic area by means of the olfactory capacities of a group of people (panel). The panel is specially trained and "calibrated" for this purpose. This method has been recently standardized by a European Norm (CEN, 2016a,b).

Two different approaches for field inspection can be applied:

- Grid method (CEN, 2016a): uses direct assessment of ambient air by panel members to characterize odour exposure in a defined assessment area;

- Plume method (CEN, 2016b): determines the extent of the downwind odour plume of a source (there is no direct relation between the presence of recognizable odours and the occurrence of odour annoyance).

Field inspections are, up to now, the only standardized method that can be used for direct odour exposure assessment. They are also very good methods for the field verification of dispersion model results (Ranzato et al., 2012; Capelli and Sironi, 2018).

\subsection{Citizen Science}

The Citizen Science approach (Paulos et al., 2009; Bonney et al., 2016) to monitoring odour harnesses the power of crowds and uses one of the most effective odour sen- sors - the human nose. Communities can record the frequency, intensity and type of odour that they experience. The combination of many individual observations can then build a clear picture of the issue. As more citizens are involved in sharing their findings, or data, the level of subjectivity is reduced. The D-NOSES project will use this technique, with the express aim to develop and validate a citizen science based bottom-up approach for odour pollution management.

\subsection{Comparison of methods}

The above-mentioned methods are based on different principles and thus can be used to provide very different types of answers. For this reason, it is difficult to make an absolute comparison of these methods. A limited comparison can be provided by stating the limits of applicability of each method, thereby clearly defining what they should, or should not, be used for. This information will be provided in the Odour Observatory, as summarized schematically in Table 1 (Capelli et al., 2019).

\section{CONCLUSIONS AND FUTURE WORK}

As stated earlier, the aim of the D-NOSES project is to develop a methodology for odour pollution management based on a bottom-up approach. The approach will focus on participatory strategies to involve citizens as well as engage quadruple helix stakeholders in the co-creation of relevant solutions.

To actively involve citizens in the process, it is important that they start with sufficient knowledge to be able to take part effectively. For this reason, the project emphasizes the accessibility of basic information such as the definition of an odour and the basic principles of odour measurement. The main channel for this will be the "International Odour Observatory", which will present simple and relevant environmental information through an easily accessible "get informed" section. The observatory will also address more sophisticated and technical audiences by offering increasingly detailed information to those that are interested.

This paper describes some of the initial information to be included in the Odour Observatory, which will provide answers to questions on how odours can be measured. An overview of the different existing odour measurement methods is given here, including a short description. The methods are distinguished based on the type of method (mathematical, instrumental or sensorial measurements) and on where they should be applied (emissions vs. ambient air). Moreover, a schematic comparison of the different methods is given in terms of their applicability and limitations.

This overview of odour measurement methods is only the first part of the information that will eventually be made available through the Odour Observatory. The next questions that will need to be answered for the development of the Odour Observatory concern: i) the available techniques that can be adopted to reduce odour emissions (odour abatement systems), ii) the presence of - potentially hazardous - chemical substances that can be found in odour 
TABLE 1: Schematization of different odour measurement methods in terms of their applicability and limitations.

\begin{tabular}{|c|c|c|c|}
\hline $\begin{array}{l}\text { Measurement } \\
\text { method }\end{array}$ & $\begin{array}{l}\text { Applicable to emissions } \\
\text { or ambient air }\end{array}$ & Applicability & Limitations \\
\hline Dynamic olfactometry & Emissions & $\begin{array}{l}\text { - Measure the concentration of odours } \\
\text { emitted at the source } \\
\text { - Ascertain if regulations are being brea- } \\
\text { ched } \\
\text { - Provide information that can be used as } \\
\text { input data for dispersion modelling in } \\
\text { order to evaluate citizens' exposure to } \\
\text { odours }\end{array}$ & $\begin{array}{l}\text { - Discontinuous method, cannot be applied to } \\
\text { the continuous measurement of odour emis- } \\
\text { sions } \\
\text { - No information about odour quality; it cannot } \\
\text { identify or discriminate different odours } \\
\text { - No information about presence of odours in } \\
\text { ambient air: it only provides information about } \\
\text { odour emissions }\end{array}$ \\
\hline $\begin{array}{l}\text { Chemical analysis - } \\
\text { with speciation }\end{array}$ & $\begin{array}{l}\text { Emissions and/ } \\
\text { or ambient air }\end{array}$ & $\begin{array}{l}\text { Obtain information about the chemical } \\
\text { composition of odours } \\
\text { - Identification and quantification of the } \\
\text { chemical compounds that are present in } \\
\text { an odour emission or in ambient air can be } \\
\text { used for the evaluation of the impact on } \\
\text { the environment and human health }\end{array}$ & $\begin{array}{l}\text { Very difficult and not always effective, espe- } \\
\text { cially in the characterization of complex } \\
\text { odours } \\
\text { Odours are not additive due to synergistic } \\
\text { and masking effects between odorants; the- } \\
\text { refore chemical composition of an odorous } \\
\text { sample can not be related to its odour concen- } \\
\text { tration } \\
\text { Less sensitive than human nose for malodo- } \\
\text { rous compounds with low odour threshold }\end{array}$ \\
\hline $\begin{array}{l}\text { Gas-chromatogra- } \\
\text { phy-Olfactometry } \\
\text { (GC-O) }\end{array}$ & Emissions & $\begin{array}{l}\text { - Gain information about the odour cha- } \\
\text { racter associated with the different mole- } \\
\text { cules contained in an odour sample, and } \\
\text { thus odour quality } \\
\text { - High sensitivity: human nose is more sen- } \\
\text { sitive than any instrumental detector; the } \\
\text { human nose is sometimes able to detect } \\
\text { the presence of odours also where the } \\
\text { chromatogram doesn't show any peak }\end{array}$ & $\begin{array}{l}\text { - No information about the odour concentration } \\
\text { of the sample. } \\
\text { Because of the separation of the sample in its } \\
\text { single components, the olfactory properties of } \\
\text { the sample as a whole are not considered } \\
\text { Cannot provide information about the odour } \\
\text { impact, and neither can it be used directly as } \\
\text { input for dispersion modelling }\end{array}$ \\
\hline $\begin{array}{l}\text { Chemical analysis - } \\
\text { non-specific }\end{array}$ & Emissions & $\begin{array}{l}\text { Detection of gas leaks, which are poten- } \\
\text { tially associated with diffuse odour emis- } \\
\text { sions } \\
\text { - Very useful in the detection of fugitive } \\
\text { emissions from equipment or piping in } \\
\text { refineries, or leaks in landfill soils }\end{array}$ & $\begin{array}{l}\text { No information about the odour properties of } \\
\text { the analyzed gas }\end{array}$ \\
\hline $\begin{array}{l}\text { Chemical analysis - } \\
\text { single gases }\end{array}$ & $\begin{array}{l}\text { Emissions and/ } \\
\text { or ambient air }\end{array}$ & $\begin{array}{l}\text { Quantify the concentration of single gases } \\
\text { in emissions or ambient air } \\
\text { - Estimate the odour concentration in emis- } \\
\text { sions, in those rare cases in which the } \\
\text { emitted odour is directly correlated to one } \\
\text { specific compound (tracer) } \\
\text { Measure the impact of odour in ambient } \\
\text { air, in those rare cases in which the odour } \\
\text { is directly correlated to one specific com- } \\
\text { pound (tracer), and the source can be uni- } \\
\text { vocally identified }\end{array}$ & $\begin{array}{l}\text { Useless in the case of complex odorous } \\
\text { mixtures, whereby odour concentration is not } \\
\text { related to the concentration of one single com- } \\
\text { ponent; this is the most common case with } \\
\text { environmental odours, which are mixtures of } \\
\text { hundreds of different compounds }\end{array}$ \\
\hline $\begin{array}{l}\text { Instrumental odour } \\
\text { monitoring (E-noses) }\end{array}$ & $\begin{array}{l}\text { Emissions and/ } \\
\text { or ambient air }\end{array}$ & $\begin{array}{l}\text { - Continuous and fast results with a limited } \\
\text { budget } \\
\text { - Continuous measurement of odour con- } \\
\text { centration at emissions, e.g., for conti- } \\
\text { nuous monitoring of the effeiciency of } \\
\text { odour abatement systems } \\
\text { - Direct determination of the odour impact } \\
\text { at receptors and identification of odour } \\
\text { provenance }\end{array}$ & $\begin{array}{l}\text { No information about intensity and pleasant- } \\
\text { ness of the odour } \\
\text { - Cannot substitute dynamic olfactometry }\end{array}$ \\
\hline Field inspections & Ambient air & $\begin{array}{l}\text { - Estimate the degree of annoyance in } \\
\text { terms of "odour hours" in a determined } \\
\text { area under investigation ("grid method") } \\
\text { - Determine the extent of the odour plume } \\
\text { from a facility under specific meteorologi- } \\
\text { cal conditions ("plume method") } \\
\text { - With a suitable training, assessors may } \\
\text { provide information about odour quality }\end{array}$ & - No information about odour concentration \\
\hline Citizen science & Ambient air & $\begin{array}{l}\text { - Involve citizens in the process of odour } \\
\text { impact assessment } \\
\text { - Estimate the degree of annoyance by di- } \\
\text { rectly referring to the effect on citizens }\end{array}$ & $\begin{array}{l}\text { - Risk of biased information } \\
\text { - Hardly applicable in conflictual situations } \\
\text { (e.g., law suits) }\end{array}$ \\
\hline
\end{tabular}

emissions, and iii) existing regulations and impact criteria regarding odour impacts in European and non-European countries.

Once collected, this information will form the basis to describe the current scientific and regulatory framework for odour pollution. It will provide a comprehensive knowledge base, considered to be a fundamental step in enabling a methodology that includes a wide range of quadruple helix stakeholders in the entire process of odour pollution management. 


\section{AKNOWLEDGEMENTS}

This project has received funding from the European Union's Horizon 2020 research and innovation programme under grant agreement No 789315.

\section{REFERENCES}

Aatamila, M., Verkasalo, P. K., Korhonen, M. J., Suominen, A. L., Hirvonen, M. R., Viluksela, M. K., \& Nevalainen, A. (2011). Odour annoyance and physical symptoms among residents living near waste treatment centres. Environ Res, 111(1), 164-170.

Ávila, B. M., Pereira, V. B., Gomes, A. O., \& Azevedo, D. A. (2014). Speciation of organic sulfur compounds using comprehensive two-dimensional gas chromatography coupled to time-of-flight mass spectrometry: A powerful tool for petroleum refining. Fuel, 126, 188-193. https://doi.org/10.1016/j.fuel.2014.02.055

Bonney, R., Phillips, T. B., Ballard, H. L., \& Enck, J. W. (2016). Can citizen science enhance public understanding of science? Public Understanding of Science, 25(1), 2-16. https://doi. org/10.1177/0963662515607406

Capelli, L., \& Sironi, S. (2018). Combination of field inspection and dispersion modelling to estimate odour emissions from an Italian landfill. Atmospheric Environment, 191, 273-290. https://doi. org/10.1016/j.atmosenv.2018.08.007

Capelli, L., Bax, C., Diaz, C., Izquierdo, C., Arias, R., \& Salas Seoane N. (2019). Review on odour pollution, odour measurement, abatement techniques, D-NOSES, H2020-SwafS-23-2017-789315. https://dnoses.eu/wp-content/uploads/2019/10/D2.1_Review-on-odour-pollution-measurement-abatement_v3.1.pdf

CEN, (2003). EN 13725:2003. Air Quality - Determination of Odor Concentration by Dynamic Olfactometry. Brussels, Belgium.

CEN (2016a). EN 16841-2:2016. Ambient air - Determination of odour in ambient air by using field inspection - Part 2: Plume method. Brussels, Belgium.

CEN, (2016b). EN 16841-2:2016. Ambient air - Determination of odour in ambient air by using field inspection - Part 1: Grid method. Brussels, Belgium.

Cipriano, D., \& Capelli, L. (2019). Evolution of Electronic Noses from Research Objects to Engineered Environmental Odour Monitoring Systems: A Review of Standardization Approaches. Biosensors, 9(2), 75. https://doi.org/10.3390/bios9020075

Conti, C., Guarino, M., \& Bacenetti, J. (2020). Measurements techniques and models to assess odor annoyance: A review. Environment international, 134, 105261. https://doi.org/10.1016/j. envint.2019.105261

Davoli, E., Gangai, M. L., Morselli, L., \& Tonelli, D. (2003). Characterisation of odorants emissions from landfills by SPME and GC/MS. Chemosphere, 51(5), 357-368. https://doi.org/10.1016/S00456535(02)00845-7

Deshmukh, S., Bandyopadhyay, R., Bhattacharyya, N., Pandey, R. A., \& Jana, A. (2015). Application of electronic nose for industrial odors and gaseous emissions measurement and monitoring-an overview. Talanta, 144, 329-340. https://doi.org/10.1016/j.talanta.2015.06.050

Guffanti, P., Pifferi, V., Falciola, L., \& Ferrante, V. (2018). Analyses of odours from concentrated animal feeding operations: A review. Atmospheric Environment, 175, 100-108. https://doi.org/10.1016/j. atmosenv.2017.12.007

Henshaw, P., Nicell, J., \& Sikdar, A. (2006). Parameters for the assessment of odour impacts on communities. Atmos Environ, 40, 10161029. https://doi.org/10.1016/j.atmosenv.2005.11.014

Kormi, T., Mhadhebi, S., Ali, N. B. H., Abichou, T., \& Green, R. (2018) Estimation of fugitive landfill methane emissions using surface emission monitoring and Genetic Algorithms optimization. Waste management, 72, 313-328. https://doi.org/10.1016/j.wasman.2016.11.024
Lucernoni, F., Capelli, L., \& Sironi, S. (2017). Comparison of different approaches for the estimation of odour emissions from landfill surfaces. Waste manage, 63, 345-353. https://doi.org/10.1016/j. wasman.2016.09.041

Marchand, M., Aissani, L., Mallard, P., Béline, F., \& Réveret, J. P. (2013). Odour and life cycle assessment (LCA) in waste management: a local assessment proposal. Waste Biomass Valori, 4(3), 607-617. https://doi.org/10.1007/s12649-012-9173-z

Paulos, E., Honicky, R. J., \& Hooker, B. (2009). Citizen science: Enabling participatory urbanism. In Handbook of research on urban informatics: The practice and promise of the real-time city (pp. 414436). IGI Global. DOI: 10.4018/978-1-60566-152-0.ch028

Ranzato, L., Barausse, A., Mantovani, A., Pittarello, A., Benzo, M., \& Palmeri, L. (2012). A comparison of methods for the assessment of odor impacts on air quality: Field inspection (VDI 3940) and the air dispersion model CALPUFF. Atmospheric Environment, 61, 570579. https://doi.org/10.1016/j.atmosenv.2012.08.009

Rodríguez-Navas, C., Forteza, R., \& Cerdà, V. (2012). Use of thermal desorption-gas chromatography-mass spectrometry (TD-GCMS) on identification of odorant emission focus by volatile organic compounds characterisation. Chemosphere, 89(11), 1426-1436. https://doi.org/10.1016/j.chemosphere.2012.06.013

Samir, S., \& Hossain, M. S. (2014). Evaluation and Applicability of Flame Ionization Detector for Fugitive Emission. In Geo-Congress 2014: Geo-characterization and Modeling for Sustainability (pp. 20522061). https://doi.org/10.1061/9780784413272.200

Singh, R. K., Ramteke, D. S., Juneja, H. D., \& Pandya, G. H. (2013). Ambient air quality monitoring in terms of volatile organic compounds (VOCs) occupational health exposure at petroleum refinery. International Journal of Environmental Protection, 3(7), 22.

Sironi, S., Capelli, L., Céntola, P., Del Rosso, R., \& II Grande, M. (2006) Odour emission factors for the prediction of odour emissions from plants for the mechanical and biological treatment of MSW. Atmos Environ, 40(39), 7632-7643. https://doi.org/10.1016/j.atmosenv.2006.06.052

Sironi, S., Capelli, L., \& Del Rosso, R., (2014). Odor Emissions, pp. 1-23. In: Elsevier Reference Module in Chemistry, Molecular Sciences and Chemical Engineering. J. Reedijk (Ed.), Elsevier, Waltham, MA.

Sironi, S., Capelli, L., Céntola, P., Del Rosso, R., \& Pierucci, S. (2010). Odour impact assessment by means of dynamic olfactometry, dispersion modelling and social participation. Atmospheric Environment, 44(3), 354-360. https://doi.org/10.1016/j.atmosenv.2009.10.029

Sowka, I., Miller, U., \& Sobczyński, P. I. O. T. R. (2016). Dynamic olfactometry and modelling as methods for the assessment of odour impact of public utility objects. Environment Protection Engineering, 42(3).

Wang, B., Sivret, E. C., Parcsi, G., Wang, X., Le, N. M., Kenny, S., ... \& Stuetz, R. M. (2014). Is H2S a suitable process indicator for odour abatement performance of sewer odours?. Water science and technology, 69(1), 92-98. https://doi.org/10.2166/wst.2013.55

Wright, D. W., Eaton, D. K., Nielsen, L. T., Kuhrt, F. W., Koziel, J. A., Spinhirne, J. P., \& Parker, D. B. (2005). Multidimensional gas chromatography- olfactometry for the identification and prioritization of malodors from confined animal feeding operations. Journal of Agricultural and food Chemistry, 53(22), 8663-8672. https://doi. org/10.1021/jf050763b

Zhang, S., Koziel, J. A., Cai, L., Hoff, S. J., Heathcote, K. Y., Chen, L., ... \& Caraway, E. A. (2015). Odor and odorous chemical emissions from animal buildings: Part 5. Simultaneous chemical and sensory analysis with gas chromatography-mass spectrometry-olfactometry. Transactions of the ASABE, 58(5), 1349-1359. doi: 10.13031/ trans. 58.11123

Zhao, Y. Lu, W., \& Wang, H. (2015). Volatile trace compounds released from municipal solid waste at the transfer stage: evaluation of environmental impacts and odour pollution. Journal of hazardous materials, 300, 695-701. https://doi.org/10.1016/j.jhazmat.2015.07.081 